\title{
Studia
}

SYNCHRONICZNE I DIACHRONICZNE ASPEKTY BADAŃ POLSZCZYZNY

www.wnus.edu.pl/sj | DOI: 10.18276/sj.2018.17-25 | 375-379

JOANNA RUTKOWSKA

Akademia im. Jakuba z Paradyża w Gorzowie Wielkopolskim

joarutajp@wp.pl

ORCID 0000-0002-2869-3553

\section{Język doświadczenia religijnego, pod red. Grzegorza Cyrana i Elżbiety Skorupskiej-Raczyńskiej, t. X, Wydawnictwo Naukowe Akademii im. Jakuba z Paradyża w Gorzowie Wlkp., Gorzów Wielkopolski 2017, ss. 313}

Doświadczanie, w tym także religijne, jest jednym z najistotniejszych aspektów egzystencji, gdyż przyjmuje nie tylko typowo religijny wymiar aktu związanego z doświadczaniem bliskości Boga, ale - może przede wszystkim - wydarzenia z życia codziennego zinterpretowanego religijnie, rozumianego jako tzw. doświadczenie życiowe ${ }^{1}$.

Tematyką powyższą zajmują się od lat naukowcy skupieni wokół konferencji pod hasłem „Język doświadczenia religijnego”, podejmujący badania dotyczące tegoż zagadnienia w różnych jego wymiarach. Od 2007 roku odbyło się dziesięć edycji spotkań naukowych, których pokłosie stanowi dziesięć tomów monografii, zaś niniejszy - X - można uznać za jubileuszowy.

Tom ów, podobnie jak wcześniejsze, jest zbiorem odzwierciedlającym kierunki badań prowadzonych przez badaczy pod wspólnym hasłem, choć w różnych ośrodkach naukowych - zarówno polskich, jak i zagranicznych. Publikacja ukazała się nakładem Wydawnictwa Akademii im. Jakuba z Paradyża w Gorzowie Wielkopolskim, a o jej wartości świadczy

${ }^{1}$ Por. Przedmowa do: Język doświadczenia religijnego, red. Grzegorz Cyran, Elżbieta Skorupska-Raczyńska, t. VI (Gorzów Wielkopolski: Wydawnictwo Naukowe Akademii im. Jakuba z Paradyża w Gorzowie Wlkp. 2014), 341. 
przede wszystkim interdyscyplinarne ujęcie zagadnień dotyczących doświadczeń, także religijnych.

Artykuły składające się na monografię, ułożone w kolejności alfabetycznej pod względem nazwisk autorów, można przypisać grupom obszarów badawczych, w których rozpatrywane jest szeroko pojęte zagadnienie doświadczenia religijnego, a są to m.in.: literaturoznawstwo, historia, pedagogika, psychologia, filozofia. Najwięcej tekstów oscyluje natomiast wokół różnych aspektów badań językoznawczych, tj. zjawisk leksykalnych, stylistycznych, frazeologicznych będących wynikiem analiz tekstów literackich o charakterze sakralnym - zarówno prozatorskich, jak i poetyckich Ponadto źródło badań stanowią m.in.: paremiologia, frazeologia, leksykografia, czasopisma czy memy internetowe.

W problematykę doświadczenia religijnego i trudności związanych z jego zdefiniowaniem wprowadza artykuł I. Skrobak pt. Doświadczenie (religijne) w opisach leksykograficznych (cz. II). Autorka zaznacza, że w źródłach leksykograficznych brak jest w zasadzie definicji pojęcia „doświadczenie religijne”, zatem do ustalenia, czym ono jest, mogą posłużyć jedynie treści dwóch odrębnych jednostek leksykalnych, tj. „doświadczenie” oraz „,religijny”, których to w słownikach odnajdujemy wiele. Wprawdzie I. Skrobak wprowadza odbiorców w tematykę publikacji, ponadto dokonuje próby zdefiniowania pojęcia, jednakże kwestię doprecyzowania definicji pozostawia odbiorcom tekstu. Oznacza to, że cykliczność konferencji, a co za tym idzie - jej pokłosia w formie monografii - jest w pełni uzasadniona.

O symbolicznym wymiarze doświadczenia religijnego pisze R. Brasse w artykule Poetyka i aksjologia doświadczenia symbolicznego na podstawie poetyki Gajcego. Analizy prowadzą do konstatacji, które zawarte są w następującej tezie: symbol w poezji Gajcego ujawnia swą wartość znaczeniową kontekstualnie, zatem doświadczenie transcendencji może być dwuznaczne. Autor artykułu wskazuje także na źródło doświadczenia symbolicznego, którym - jego zdaniem - jest identyfikacja ze świadomością twórczą zawartą w danym dziele. Artykuł stanowi zatem swoistą odpowiedź na pytanie o źródło, funkcje i skutki doświadczenia religijnego - także w jego ujęciu symbolicznym.

Doświadczenia religijne Orhana Pamuka stały się bazą do badań prowadzonych przez L.A. Suchomłynowa, który dokonał analizy i interpretacji powieści Stambut. Wspomnienia i miasto. Autor artykułu przybliża zarówno sylwetkę pisarza, jak i treść powieści, co stanowi kanwę dalszych rozważań - w aspekcie problematyki religijnej, którą prozaik traktuje jak odrębny, autonomiczny wątek jego utworów. Religijność w ujęciu Pamuka jest związana z utraconymi tradycjami ormiańskimi.

Istotę formy jako środka artystycznego w odniesieniu do doświadczenia przybliża M. Nowak. Poprzez analizę zbioru psalmów Autorka artykułu pt. Doświadczenie religijne a forma jako środek artystyczny (Akrostychy w psatterzu Henryka Adamczyka) dokonuje oceny próby translatorskiej mającej na celu oddanie chwały Bogu i wyrażenia względem Niego uwielbienia w najwyższym wymiarze. Wyniki badań składają się na szczegółową i interesującą analizę akrostychów znajdujących się w wyżej wymienionym zbiorze psalmów. 
O tradycjach religijnych w społeczeństwie szwajcarskim pisze natomiast L. Tobiasz. Badacz w swoim artykule dotyczącym szwajcarskiego Kościoła katolickiego i przemian społeczno-kulturowych przedstawia zarys historii krajobrazu religijnego na obszarze współczesnej Szwajcarii od czasów rzymskich do końca lat czterdziestych XX wieku, następnie zaś podkreśla rolę i rangę wspólnoty religijnej, ale - co najistotniejsze - wskazuje także na jej przemiany na przestrzeni lat. W konkluzji zaznacza tęsknotę członków społeczności za powrotem do tradycji i korzeni religijnych, co w obecnej sytuacji kraju nie jest łatwe.

Codzienne życie mieszkańców Galicji Wschodniej jest przedmiotem badań W. Welykoczego. W artykule Życie codzienne w Galicji Wschodniej w okresie wojenno-rewolucyjnym (1914-1919) w ukraińskiej historiografii: wybrane aspekty kulturowe Autor w sprawozdawczej formie przedstawia aspekty edukacyjne, gospodarcze, socjologiczne, religijne, poszukuje rozwiązań różnorodnych problemów dotyczących tego obszaru.

Doświadczenie religijne może przyjmować także wymiar filozoficzny i być rozpatrywane w takim kontekście, co poświadcza M. Jaworska-Wołoszyn. W artykule Religia i pobożność w ,Traktacie o cnotach” Georgiosa Gemistosa (Plethona) dokonuje próby zdefiniowania pojęć religia i pobożność na materiale Traktatu o cnotach w rozumieniu Plethona. Tak pojmowane doświadczanie religijne pokazuje jego odwieczny związek z wiarą, religią oraz jego funkcję jako nieodłącznego elementu towarzyszącego człowiekowi już od czasów najdawniejszych. Religia zaś - według G. Gemistosa - jako jedyna wiedzie człowieka do pełnego szczęścia, gdyż umożliwia poznanie, a co za tym idzie - doświadczenie Najwyższego.

Ujęcie pedagogiczno-psychologiczne prezentuje natomiast D. Skrocka, która w artykule pt. Pycha i próżność vs pokora. O możliwości wychowania człowieka świadomego własnej niedoskonałości bada zależności między pokorą a pychą i próżnością w kontekście wychowania człowieka świadomego własnej niedoskonałości. Autorka dokonuje analizy pojęć $\mathrm{w}$ różnych ujęciach i na bazie różnorodnych źródeł, wskazuje na związek tychże z doświadczaniem codziennym, zaś w konstatacji „Pycha kroczy przed upadkiem, a wielkie rzeczy cicho płyną" (s. 227) jawi się dydaktyczny aspekt artykułu.

Religia i jej doświadczanie ma związek z historią, patriotyzmem i ojczyzną, co podkreśla P. Słowiński w artykule dotyczącym wydarzeń związanych z chrztem Polski. Autor przedstawia historię przygotowań do jubileuszu, nakreśla okoliczności z nim związane, przebieg wydarzenia, a także dokonuje analiz listów duszpasterskich wydanych z tej okazji, opublikowanych na łamach „Gorzowskich Wiadomości Kościelnych”. Interdyscyplinarny tekst artykułu aspekty religijne ujmuje w ramy historyczno-językowo-socjologiczne.

Jako zewnętrzny wymiar doświadczania religijnego badacze opublikowanych artykułów przywołują elementy kultu religijnego, np. znaki i symbole. Na bogatym materiale przysłów i związków frazeologicznych E. Skorupska-Raczyńska w interesujący i wyczerpujący sposób prezentuje konceptualizację krzyża - najważniejszego symbolu religijnego w kulturze polskiej. Autorka wskazuje na niezwykle bogate znaczenie krzyża ze względu na jego wielorakie przyporządkowanie funkcjonalne, czego odzwierciedlenie stanowi 
ponad 140 jednostek nawiązujących do tego symbolu. Potwierdzeniem znaczącego i dawnego umocowania krzyża jak znaku, symbolu i desygnatu w kulturze polskiej jest ludowa proweniencja większości analizowanych przez E. Skorupską-Raczyńską paremii z komponentem krzyż.

W tekstach zawartych w monografii przywołuje się postaci Boga Ojca, Chrystusa, a także świętych. K. Czarnecka w artykule „Ten, który żyje we mnie...”-uwagi o pewnym typie opisowych określeń Boga w zapiskach pamiętnikarskich Błogosławionej Natalii Tutasiewiczówny w interesujący sposób prezentuje wyniki badań dotyczących nazwań Boga, do których zalicza przede wszystkim peryfrazy, w tym specyficzny rodzaj deskrypcji inicjowanych konstrukcją „Ten, który...” Z przywoływanych określeń wyłania się obraz Boga bliskiego, wspierającego, będącego źródłem wszelkiego dobra.

M. Maczel natomiast prezentuje wyniki badań językoznawczych skupiających się głównie wokół postaci Jezusa. Analizy dokonane zostały na materiale dramatu Judasz z Kariothu K.H. Rostworowskiego, a ich bazą były przede wszystkim wypowiedzi bohaterów nawiązujące i do osoby Chrystusa, i do nauki przez Niego głoszonej, z czego wynikają różne postawy względem nowego proroka: pełna wiary i oddania (prezentowana przez apostołów i Rachelę), przepełniona duchowymi rozterkami, a nawet wskazująca na brak wiary (Judasz) czy wroga i pogardliwa (rządzący Judeą). Wymienione wyżej typy postaw względem Boga nie są obce ludziom czasów współczesnych.

Postać św. Józefa jawi się w artykule Językowa kreacja Józefa Cieśli w powieści J. Dobraczyńskiego „Cień ojca” R. Janickiej-Szyszko. Eksponowany jest przede wszystkim profil dobrego, prawego, opiekuńczego męża Maryi i opiekuna Jezusa, ale także rzemieślnika o wyjątkowej fachowości - wszystkie tworzone za pomocą zróżnicowanych środków językowych, które Autorka skrupulatnie analizuje.

Sylwetkę innego świętego - Maksymiliana Marii Kolbego - przybliża E. Tobiasz w artykule Dziedzictwo świętego Maksymiliana Marii Kolbego. Autorka przywołuje postawę zakonnika walczącego o Kościół poprzez podejmowanie przez niego misyjnych działań, szerzenie kultu Matki Bożej, przede wszystkim zaś wskazuje na jego wzorcową postawę chrześcijańską względem Boga i człowieka. Artykuł ma zatem znamiona wychowawczo-dydaktyczne.

W analizowanym tomie nie brakuje także elementów biblijnych, tj. nawiązań do historii Świętej Rodziny. Biblijne odniesienia w wierszach Julii Hartwig są przedmiotem badań J. Rychter, według której poetka w mistrzowski sposób wykorzystuje wydarzenia przywoływane w Biblii, poddając je reinterpretacji i czyniąc $z$ nich bazę do nadbudowywania nowych sensów - tu, podobnie zresztą jak we wspomnianym wyżej artykule M. Maczel odnajdujemy skupienie uwagi Autorki na rozterkach współczesnego człowieka, wynikające z konfliktu wywołanego sprzecznościami, jak osiągnięcia nauki i techniki z jednej strony a wielowiekową tradycją chrześcijańską z drugiej. W interesującym artykule pt. Odniesienia religijne $w$ tomiku „Zapisane” Julii Hartwig mowa jest także o leksyce i stylistyce, którymi posługuje się i które wykorzystuje poetka. 
Doświadczenie religijne ma swój oddźwięk także w komunikacji internetowej, o czym świadczy artykuł A.A. Niekrewicz Internetowe memy religijne-od bluźnierstwa do przeżyć religijnych. Autorka w przejrzysty sposób analizuje religijne memy internetowe, wskazuje ich funkcje, przeznaczenie i wymiar, przede wszystkim zaś podkreśla ich różnorodność pod względem formy, poziomu, kształtu graficznego przy ich niezmienności pod względem cech stylistycznych.

Zagadnienia onomastyczne, tj. nazewnictwo ulic, są bazą do rozważań podjętych przez J. Dubiec-Stach. Autorka docieka konotacji religijnych ulic Gorzowa Wielkopolskiego i Skwierzyny w trzech historycznych momentach: na przełomie roku 1944/1945, lata 1945-1950 oraz w roku 2016. Po krótkim wprowadzeniu w historię miasta i miasteczka zostaje przedstawiony podział konotacji pod względem ich treści: geograficznej, wiekowej, socjologicznej, polityczno-ideologicznej oraz religijnej, której Autorka poświęca szczególną uwagę przy badaniu materiału właśnie w obrębie wyznaczników tejże konotacji, co na potrzeby artykułu jest w pełni uzasadnione. Wyniki analiz wskazują na nieliczne konotacje religijne nazewnictwa ulic w każdym badanym okresie.

Doświadczanie w każdym wymiarze stanowi niezgłębione źródło badań, jego wielowymiarowość i wieloaspektowość jest nieodłącznym elementem egzystencji, dlatego staje się przyczynkiem do kolejnych analiz i wniosków. Ma charakter emocjonalny i percepcyjny, dotyczy rozmaitych przeżyć człowieka w relacji do obiektów i przekonań właściwych dla tradycji religijnej, w której owe przekonania zostały ukształtowane ${ }^{2}$.

Podsumowując przegląd tekstów dotyczących powyższego zagadnienia, zawartych w publikacji Język doświadczenia religijnego, t. X, należy podkreślić przede wszystkim ich interdyscyplinarność, ujęcie w wielu aspektach i dziedzinach nauki, różnorodną metodologię badań, co przekłada się zarówno na wysoki poziom poszczególnych artykułów, jak i monografii. Jej rangę podnosi także autorstwo badaczy polskich i zagranicznych. Publikowany corocznie od dziesięciu lat kolejny - tym razem X - tom monografii zawiera znaczący dorobek naukowy i badawczy, ponadto stanowi dopełnienie analiz z lat ubiegłych, jednocześnie zaś otwiera kolejne drogi badań nad doświadczaniem - nie tylko w ujęciu stricte religijnym.

${ }^{2}$ Por. Przedmowa do: Język doświadczenia religijnego, red. Grzegorz Cyran, Elżbieta SkorupskaRaczyńska, t. VIII (Gorzów Wielkopolski: Wydawnictwo Naukowe Akademii im. Jakuba z Paradyża w Gorzowie Wlkp. 2015), s. 7. 